\title{
Environmental Efficiency Policies Related to Porter's Hypothesis
}

\author{
Muryani \\ Economic and Business Faculty \\ UniversitasAirlangga \\ Surabaya, Indonesia \\ muryani2008@yahoo.co.id
}

\begin{abstract}
Indonesia as one of the countries of the G20 with the manufacturing sector as one of the largest energy user sectors. Energy use in the industrial sector is contributing as emitters. The greater use of energy, the greater the amount of emissions produced. The need for environmental policy declared by Jaffe et al (1995) in his research called Porter's Hypothesis, namely environmental policies may affect innovation and market creation. But in the long-term costs of policy or government spending is specialized in the field of environment will benefit the government itself which will increase the level of the efficiency of the country. This study aims to analyze how the level of efficiency of the manufacturing sector in the city - metropolitan city in Indonesia under natural policy and managerialdisposabilitypolicy. Secondly, this study try to analyze and find the causes of inefficiency variables, where the role of technological innovation is very important in increasing the level of efficiency both operational and environmental performance. The data sample is 33 provinces within Indonesia. By compositing six variables, which is three input variables and three output variables. The output variable consists of desirable output(good output) and undesirable output (bad output). The input variables consist of labor, investment, and energy consumption, while the output variable consists of the GDP, SO2, and NO2. The research utilized Data Envelopment Analysis (DEA). The research result is the efficiency in the manufacturing sector in $\mathbf{3 3}$ provinces in Indonesia with two ways of measurement that has been determined by using arithmetic models shows that the province of large provinces such as Jakarta and West Java has a high efficiency in the industrial sector. For example, Jakarta has an average efficiency of $100 \%$ perfect in UENM efficiency measurements during the observation period 2012-2015.
\end{abstract}

Keywords-efficiency; policy; input; output; DEA

\section{INTRODUCTION}

Energy use in the industrial sector contributed as emitters in many countries, especially developing countries. The greater use of energy, the greater the amount of emissions produced. At first, the relationship between the energy with the environment has not been a major concern. Environmental conditions are thus becoming its own demands for all countries to pay attention to energy utilization in the process of economic development in order to achieve economic sustainability. Energy utilization concept is to increase the process of industrialization and urbanization, and environmental issues all of them can be regarded as a process unit, which implicitly will encourage growth in the production and consumption of energy [1].

Sustain economic development itself is a balance between the growth of energy, economy and environment. Among these three factors of energy is the most influential factor in economic growth, and economic growth also depends on the use of energy for economic development of the country [2]. When economic growth is getting faster and maximize all possible energy sector, then in the process of economic growth was also natural resources, including energy resources that are used on a large scale creates emissions on a large scale as well. Therefore, the existence of a policy that takes into account environmental conditions are very necessary.

The need for environmental policy is also expressed by [3] in his research called Porter's Hypothesis, namely environmental policies may affect innovation and market creation but in the long term costs of policy or government spending is specialized in the field of environment will benefit the government itself which will improve the level of efficiency of the country. Various techniques or energy planning models can be built from the simplest to the most complex. And in general the model is divided into five main approaches, namely the process approach, the approach trend, elasticity approach, econometric approach, and the approach of input-output [4].

DEA is a non-parametric method that measures the efficiency of using the Decision-Making Unit (DMU) [5]. When compared to SFA, DEA does not require any particular function relationship between input to output of production or distribution assumptions error. Unlike SFA, DEA allows the use of multiple input and output. DEA also generates detailed information value the efficiency of the unit, not only relative to the efficiency frontier, but also against certain efficiency units that are more specific and more can be used as a benchmark or comparison [6]. Several previous studies like [7], [8], [1] have used the technique DEA in measuring the level of environmental efficiency. 


\section{THEORETICAL SUPPORT}

The use of DEA (Data Envelopment Analysis) in assessment environment, this study used two strategies related to the concept of environmental protection (environmental protection). One of these two concepts refer to the "natural disposability" indicating that each DMU (Decision Making Unit) which lowers the input unit, will reduce the unwanted output unit (output bad). In short, each DMU will increase the vector direction of the desired output as much as possible.

Fig. 1 illustrates the presence of two strategies adapted to the time change in policy. The first strategy is natural disposability and the second is managerial disposability. Natural disposability indicated that each DMU decrease the number of inputs in order to reduce any undesirable output. These types of strategies to maximize existing resources by using technology, but at its growth, It derived from the merger between operational efficiency and environmental efficiency to achieve efficiency levels with specific frontier production function $\mathrm{g} 0=\mathrm{fO}$ (b). The second strategy is a strategy that refers to the use of technology and innovation or other types of managerial turnover that shifts the function $\mathrm{g} 0$ to $\mathrm{g} 1=\mathrm{f} 1$ (b) to explain how the production process takes place when their technological innovations. Each DMU operating performance, supported by technological innovations can be found on line production function $\mathrm{g} 1$ = f1 (b). As described above, the two concepts disposability derived from corporate strategy to adapt to the current changes in the regulation of the output undesireable.

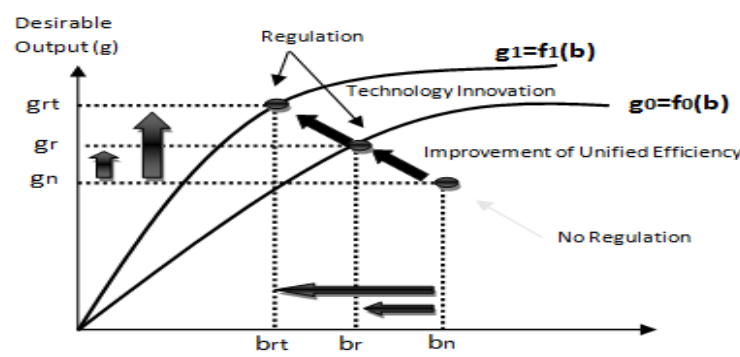

Fig. 1. Natural and Managerial Disposability with technology innovation[9].

\section{RESEARCH METHODOLOGY}

\section{A.Analysis Tools}

Formulations for measurement combined efficiency (operational\& environmental). The combined performance (the operational and environmental) of each DMU is characterized by activities that maximize production inputs separately produce not only desirable but also undesireable output. All input, output desireable and undesireable categorized as a factor of production. The research was realized that there are $n$ DMU which will be evaluated using the DEA. The most important of the use of DEA in this study was the achievement of each DMU DMU which can be compared with the other. "Performance levels" at Interpret through "efficiency score" or "efficiency measures".
Symbol mathematics used to express factors of production in DEA as follows: $X_{j}=\left(X_{1 j}, X_{2 j}, \ldots, X_{m j}\right)^{T}>0$, $\mathrm{g}_{\mathrm{j}}=\left(\mathrm{g}_{1 \mathrm{j}}, \mathrm{g}_{2 \mathrm{j}}, \ldots, \mathrm{g}_{\mathrm{sj}}\right)^{\mathrm{T}}>0, \operatorname{danBj}=\left(\mathrm{b}_{1}, \mathrm{~b}_{2}, \ldots, \mathrm{b}_{\mathrm{hj}}\right)^{\mathrm{T}}>0$ for $\mathrm{j}=$ $1, \ldots, n$. T indicates the vector of the variables that have been transposed. Inequality $(>)$ indicates that all three components of the vector field is positive. Furthermore, it is important for researchers to pay attention to slack variable variable subsequently associated with the input, desireable and undesireable output: $\mathrm{d}_{\mathrm{i}}{ }^{\mathrm{x}} \geq 0$ for every $i=1$, $\ldots, \mathrm{m}, \mathrm{d}_{\mathrm{r}}^{\mathrm{g}} \geq 0$ for every $\mathrm{r}=1, \ldots, \mathrm{s}$, and $\mathrm{d}_{\mathrm{f}}^{\mathrm{b}} \geq 0$ for $\mathrm{f}=1, \ldots$, $h$. for each model of DEA research always requires $\Lambda=$ $(\Lambda 1, \ldots, \Lambda \mathrm{n})^{\mathrm{T}}$ to describe the intensity of the unknown or variable structural. Then the following is the range of data associated with the input, desireable and undesireable output:

$\mathrm{R}_{\mathrm{i}}{ }^{\mathrm{x}}=(\mathrm{m}+\mathrm{s}+\mathrm{h})^{-1}\left(\max \left\{X_{\mathrm{ij}} \mathrm{j}=1, \ldots, \mathrm{n}\right\}-\min \left\{X_{\mathrm{ij}} \mathrm{j}=1\right.\right.$, $\ldots, \mathrm{n}\})^{-1}$ untuki $=1, \ldots, \mathrm{m}$,

$\mathrm{R}_{\mathrm{r}}^{\mathrm{g}}=(\mathrm{m}+\mathrm{s}+\mathrm{h})^{-1}\left(\max \left\{\mathrm{g}_{\mathrm{r} j} \mathrm{j}=1, \ldots, \mathrm{n}\right\}-\min \left\{\mathrm{g}_{\mathrm{rj}} \mathrm{j}=1\right.\right.$, $\ldots, \mathrm{n}\})^{-1}$ untuk $\mathrm{r}=1, \ldots, \mathrm{s} \&$

$\mathrm{R}_{f}^{\mathrm{b}}=(\mathrm{m}+\mathrm{s}+\mathrm{h})^{-1}\left(\max \left\{\mathrm{b}_{f \mathrm{j}} \mathrm{j}=1, \ldots, \mathrm{n}\right\}-\min \left\{\mathrm{b}_{f \mathrm{j}} \mathrm{j}=1\right.\right.$, $\ldots, \mathrm{n}\})^{-1}$ untukf $=1, \ldots, \mathrm{h}$

The third range of data is identified through a group of observational data that have been obtained prior to the DEA assessment. Research [9] have specified non-radial models to measure the combined efficiency of the K-th DMU where $\mathrm{k}$ is the specific DMU will be evaluated:

Maximize $\sum_{i}^{m}={ }_{1} \mathbf{R}_{i}^{\mathrm{x}}\left(\mathrm{d}_{i}^{x}+\mathrm{d}_{i}^{x-}\right)+\sum_{r}{ }^{s}={ }_{1} \mathbf{R}_{r}{ }^{g} \mathrm{~d}_{r}{ }^{g}+\sum_{f}^{b}=$ ${ }_{1} \mathbf{R}_{f}^{b} \mathrm{~d}_{f}^{b}$

$$
\begin{aligned}
& \text { s.t. } \quad \sum_{j}^{n}={ }_{1} x_{i j} K_{j}-\mathrm{d}_{i}^{x+}+\mathrm{d}_{i}^{x-}=x_{i k}(i=1, \ldots, m) \text {, } \\
& \sum_{j}^{n}={ }_{1} \mathrm{~g}_{r j} K_{j}-\mathrm{d}_{r}^{g}=\mathrm{g}_{r k}(r=1, \ldots, s), \\
& \sum_{j}^{n}={ }_{1} \mathrm{~b}_{f j} K_{j}-\mathrm{d}_{f}^{b}=\mathrm{b}_{f k} \quad(f=1, \ldots, h), \\
& \sum_{j}^{n}={ }_{1} K_{j}=1, \Lambda_{j} \geq 0 \quad(\mathrm{j}=1, \ldots, \mathrm{n}), \\
& \mathrm{d}_{i}^{x+} \geq 0(i=1, \ldots, m), \mathrm{d}_{i}^{x-} \geq 0(i=1, \ldots, m), \\
& \mathrm{d}_{r}^{g} \geq 0(r=1, \ldots, s) \& \mathrm{~d}_{f}^{b} \geq 0(f=1, \ldots,
\end{aligned}
$$

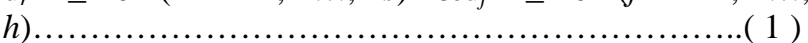

after completing the model (1), the combined efficiency level of the k-th DMU is determined by:

$\mathrm{UE}=1-\left(\sum_{i=1}^{m} R_{i}^{x}\left(d_{i}^{x+*}+d_{i}{ }^{x-*}\right)+\sum_{r=1}^{s} R_{r}^{g}{ }_{r} d^{g^{*}}{ }_{r}+\sum_{f=1}^{h} R_{f}^{b} d^{b^{*}}{ }_{f}\right.$

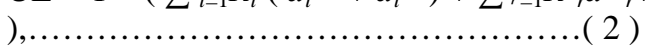

Where all the slack is all that are enclosed in parentheses are obtained through optimization calculation model (1).

To combine the two types of disposability in conjunction with a separate input and output, this study offers a model for the non-radial k-th DMU as follows:

$$
\begin{aligned}
& \text { Maximize } \quad \sum_{i}^{m}={ }_{1} \mathrm{R}_{i}{ }^{\mathrm{x}} \mathrm{d}_{i}{ }^{x}+\sum_{r}^{s}={ }_{1} \mathrm{R}_{r}{ }^{g} \mathrm{~d}_{r}^{g}+\sum_{f}^{h}={ }_{1} \mathrm{R}_{f}^{b} \mathrm{~d}_{f}^{b} \\
& \text { s.t. } \quad \sum_{j}^{n}={ }_{1} X_{\mathrm{ij}} K_{\mathrm{j}}-\mathrm{d}_{i}{ }^{x}=X_{i k}(i=1, \ldots, m) \text {, } \\
& \sum_{j}^{n}={ }_{1} \mathrm{~g}_{r j} K_{j}-\mathrm{d}_{r}^{g}=\mathrm{g}_{r k}(r=1, \ldots, s), \\
& \sum_{j}^{n}={ }_{1} \mathrm{~b}_{f j} K_{j}-\mathrm{d}_{f}^{b}=\mathrm{b}_{f k} \quad(f=1, \ldots, h), \\
& \sum_{j}^{n}={ }_{1} K_{j}=1 \text {, } \\
& \kappa_{j} \geq 0 \quad(j=1, \ldots, \mathrm{n}), \mathrm{d}_{i}^{x} \geq 0(i=1, \ldots, m), \mathrm{d}_{r}^{g} \geq 0(r=1, \\
& \ldots, s), \&
\end{aligned}
$$




$$
\begin{aligned}
& \mathrm{d}_{f}^{b} \quad \geq \quad 0 \quad(f \quad=\quad 1, \quad \ldots, \\
& \mathrm{UEN}=1-\left(\sum_{i=1}^{m} \mathrm{R}_{i}^{\mathrm{x}} \mathrm{d}_{i}^{x^{*}}+\sum_{r=1}^{s} R_{r}^{g} d_{r}^{g^{*}}+\sum_{f=1}^{h} R_{f}^{b} d_{f}^{b^{*}}\right.
\end{aligned}
$$

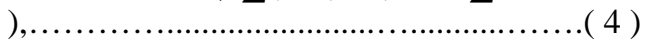

$$
\begin{aligned}
& \text { Maximize } \sum_{i}^{m-}={ }_{1} \mathrm{R}_{i}^{\mathrm{x}} \mathrm{d}_{i}{ }^{x-}+\sum_{q}{ }^{m+}={ }_{1} \mathrm{R}_{q}{ }^{\mathrm{x}} \mathrm{d}_{q}{ }^{x+}+\sum_{r}{ }_{r}={ }_{1} \mathrm{R}_{r}{ }^{g} \mathrm{~d}_{r}^{g} \\
& +\sum_{f}^{h}={ }_{1} \mathbf{R}_{f}^{b} \mathrm{~d}_{f}^{b} \\
& \text { s.t. } \quad \sum_{j}^{n}={ }_{1} X^{-}{ }_{\mathrm{ij}} \mathcal{K}_{\mathrm{j}}-\mathrm{d}_{i}^{x-}=X^{-}{ }_{i k}\left(i=1, \ldots, m^{-}\right) \text {, } \\
& \sum_{j}^{n}={ }_{1} X^{+}{ }_{\mathrm{qj}} K_{\mathrm{j}}-\mathrm{d}_{q}{ }^{x-}=X^{+}{ }_{q k}\left(q=1, \ldots, m^{+}\right), \\
& \sum_{j}^{n}={ }_{1} \mathrm{~g}_{r j} K_{j}-\mathrm{d}_{r}^{g}=\mathrm{g}_{r k}(r=1, \ldots, s), \\
& \sum_{j}^{n}={ }_{1} \mathrm{~b}_{f j} K_{j}-\mathrm{d}_{f}^{b}=\mathrm{b}_{f k} \quad(f=1, \ldots, h), \\
& \sum_{j}^{n}={ }_{1} K_{j}=1, \\
& \Lambda_{j} \geq 0(j=1, \ldots, \mathrm{n}), \mathrm{d}_{i}^{x-} \geq 0\left(i=1, \ldots, m^{-}\right), \\
& \mathrm{d}_{q}{ }^{x+} \geq 0\left(q=1, \ldots, m^{+}\right), \mathrm{d}_{r}^{g} \geq 0(r=1, \ldots, s), \& \mathrm{~d}_{f}^{b} \geq \\
& 0(f=1, \ldots, h) \ldots \ldots \ldots \ldots \ldots \ldots \ldots \ldots \ldots \ldots . . .5 \%
\end{aligned}
$$

Can be seen on the model (3), one of the two groups using inputs that have slack $\left(\mathrm{d}_{\mathrm{i}}^{\mathrm{X}-}\right.$ for $\left.i=1, \ldots, \mathrm{m}^{-}\right)$is positive under natural disposability, while the other group with which inputs have slack $\left(\mathrm{d}_{\mathrm{q}}{ }^{\mathrm{x}}\right.$ for $\left.q=1, \ldots, \mathrm{m}^{+}\right)$is a negative value under managerial disposability.

UENM (Unified Natural and Managerial Efficiency under disposability) of the k-th DMU can be calculated by:

$\mathrm{UENM}=1-\left(\sum_{i=1}^{m_{-}} \mathrm{R}_{i}^{\mathrm{x}} \mathrm{d}_{i}^{x-{ }^{*}}+\sum_{q=1}^{m+} \mathrm{R}_{q} \mathrm{~d}_{q} \mathrm{~d}^{x+*}+\right.$

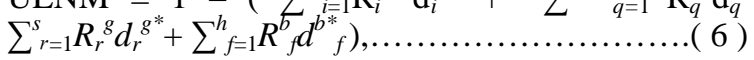

Where all the slack out of all of the variables are calculated through models (3). Similarities in parentheses obtained from the optimization model (3), which indicates the level of inefficiency combined. UENM calculated by reducing the level of efficiency of absolute efficiency Fig. 1.

\section{B. Data Resources}

In this research is important to examine the comparison of effectiveness between two policies, namely natural unnatural policy and policy using a sample 33 provinces in Indonesia. The data used in the time range was between 2012 to 2015 by 33 DMU (Decision Making Unit), namely Aceh, North Sumatra, West Sumatra, Riau, Jambi, South Sumatra, Bengkulu, Lampung, Bangka Belitung, Riau Islands, Jakarta, West Java, Central Java, Yogyakarta, east Java, Banten, Bali, NTB, NTT, West Kalimantan, Central Kalimantan, South Kalimantan, east Kalimantan, north Sulawesi, Central Sulawesi, South Sulawesi, Southeast Sulawesi, Gorontalo, West Sulawesi, Maluku, north Maluku, west Papua, and Papua.

\section{Operational Definition}

This study uses six types of variables: three variable input and three output variables that can all be accessed through the Central Statistics Agency (BPS), Indonesia and reports Ministry of Environment and Forests (KLHK) of the Republic of Indonesia, the data can be accessed either through the library BPS and the Ministry of Environment and publications and menlhk.go.id bps.go.id website.
Variable input is energy consumption that is energy used in the manufacturing sector in the city, the labor force of the active labor force works in the districts / cities surveyed, and the investment that foreign investment in the districts / cities surveyed.Variable output are classified into two parts, namely the output desireable and undesireable output. Desireable output used in this study is in the form of GDP is the output of a region that comes and economic activities in the area, while the output undesireable used in this study is Nitrogen Dioxide (NO2) and sulfur dioxide (SO2).

\section{IV.RESULTS OF RESEARCH}

\section{A. Overview}

Table 1 is the Classification Input for measurement UENM. Classification under the input is only used in the measurement UENM and not for UEN. Incompatibility classification input is allowed, but will produce UENM that is not how big [10].

Manufacturing Industry indicate that the average of the GDP increase along with the observation period. For example, the average the GDP stood at 61840.55 billion in $2012,68026.79$ billion in 2013, and continued to rise in the numbers 83443.06 billion in 2015 . In addition the

\section{TABLEI. CLASSIFICATION INPUTFOR UENM}

\begin{tabular}{|c|c|}
\hline $\begin{array}{c}\text { Decrease for Operational } \\
\text { Efficiency }\end{array}$ & $\begin{array}{c}\text { Increase for } \\
\text { Environmental } \\
\text { Efficiency }\end{array}$ \\
\hline $\begin{array}{c}\text { Cabor (L) Capital asset (K) } \\
\text { Decrease to attain } \\
\text { Increase investment } \\
\text { to facilitate } \\
\text { technology } \\
\text { operationalefficiency } \\
\text { innovation in capital } \\
\text { assets }\end{array}$ \\
\hline Energy (E) & \\
\hline Decrease to attain & \\
\hline
\end{tabular}

average number of undesireable outputs, $\mathrm{SO}_{2(\mathrm{X})}$ and $\mathrm{NO}_{2(\mathrm{X})}$ have decreased in the period of observation. For example, in the early years of observation, 2012, the amount of sulfur dioxide $\left(\mathrm{SO}_{2}(\mathrm{X})\right)$ reached 11.78 metric tons, and continuously decrease until it reaches 6.92 metric tons in 2015. Similarly, the nitrogen dioxide $\left(\mathrm{NO}_{2}\right.$ (X)), with starting at 12:27 figures metric tons of emissions of NO2 (X) in 2012, and continues to decline reached 10:42 metric tons in 2015.

In addition to indicating a trend of desireable and undesireable output, showed a declining trend in labor input (L) and an increase in investment $(\mathrm{K})$ during the observation period. For example, in 2012 the index Labor Force ParticipationRate (LFPR) in Indonesia reached $67.73 \%$, the rate may continue to fall but was increased in 2014 from $66.23 \%$ figure in 2013 to $66.84 \%$, but Indonesia can return suppress the level of labor utilization so LFPR in 2015 stood at $66.6 \%$.

Unfortunately, increasing investment trend seems not how to influence the energy consumption rate of themanufacturing industry in Indonesia. The level of energy consumption is expected to experience a 
downward trend did not occur in Indonesia as a previous study conductedin Japan (Otsuka, 2014). In 2012 for example, the energy consumption of manufacturing industries in Indonesia reached $1598 \mathrm{Mwh}$, and continued to increase until the end of the observation period in 2015 to $1979 \mathrm{Mwh}$.

\section{B. Results}

Indonesia consists of 34 provinces are lined up from north to south of the equator. Kalimantan province north as the newly opened in 2014 it had not entered into the observation area because of data limitations, however, the essence of this study is not reduced. In Table 2 shows the results of measurement of efficiency in the manufacturing sector in 33 provinces in Indonesia with two ways of measurement that has been determined by using arithmetic models (3) and (5). Table 2 shows that the province of large provinces such as Jakarta and West Java shows the measurement results of high efficiency in the industrial sector. For example, Jakarta has an average efficiency of $100 \%$ perfect in UENM efficiency measurements during the observation period 2012-2015.

\section{TABLEII. RESULTS UEN EFFICIENCY AND UENM} 33 PROVINCES IN INDONESIA

\begin{tabular}{|c|c|c|c|c|c|c|c|c|c|}
\hline \multirow[b]{2}{*}{ No } & \multirow[b]{2}{*}{ Provinsi } & \multicolumn{2}{|c|}{2012} & \multicolumn{2}{|c|}{2013} & \multicolumn{2}{|c|}{2014} & \multicolumn{2}{|c|}{2015} \\
\hline & & UEN & UENM & UEN & UENM & UEN & UENM & UEN & UENM \\
\hline 1 & ACEH & 0.89 & 0.99 & 0.87 & 0.95 & 0.88 & 0.98 & 0.34 & 0.99 \\
\hline 2 & $\begin{array}{c}\text { SUMATRA } \\
\text { UTARA } \\
\end{array}$ & 0.47 & 0.90 & 0.14 & 0.86 & 0.37 & 0.92 & 0.00 & 0.82 \\
\hline 3 & $\begin{array}{c}\text { SUMATRA } \\
\text { BARAT } \\
\end{array}$ & 0.50 & 0.98 & 0.65 & 0.97 & 0.72 & 0.94 & 0.24 & 1.00 \\
\hline 4 & RIAU & 0.00 & 1.00 & 0.00 & 1.00 & 0.00 & 1.00 & 0.00 & 1.00 \\
\hline 5 & JAMBI & 0.61 & 0.96 & 0.20 & 1.00 & 0.00 & 1.00 & 0.66 & 0.95 \\
\hline 6 & $\begin{array}{l}\text { SUMATRA } \\
\text { SELATAN }\end{array}$ & 0.43 & 0.90 & 0.47 & 1.00 & 0.55 & 0.88 & 0.56 & 0.83 \\
\hline 7 & BENGKULU & 0.95 & 1.00 & 0.95 & 1.00 & 0.75 & 1.00 & 0.85 & 1.00 \\
\hline 8 & LAMPUNG & 0.15 & 1.00 & 0.00 & 1.00 & 0.10 & 1.00 & 0.49 & 1.00 \\
\hline 9 & $\begin{array}{c}\text { BANGKA } \\
\text { BELITUNG }\end{array}$ & 0.49 & 0.98 & 0.73 & 0.94 & 0.81 & 0.94 & 0.78 & 0.90 \\
\hline 10 & $\begin{array}{c}\text { KEPULAUAN } \\
\text { RIAU } \\
\end{array}$ & 0.00 & 0.94 & 0.00 & 1.00 & 0.00 & 1.00 & 0.00 & 0.89 \\
\hline 11 & $\begin{array}{c}\text { DKI } \\
\text { JAKARTA } \\
\end{array}$ & 0.52 & 1.00 & 0.57 & 1.00 & 0.59 & 1.00 & 0.58 & 1.00 \\
\hline 12 & JAWA BARAT & 0.00 & 1.00 & 0.00 & 1.00 & 0.00 & 1.00 & 0.00 & 1.00 \\
\hline 13 & $\begin{array}{c}\text { JAWA } \\
\text { TENGAH }\end{array}$ & 0.00 & 1.00 & 0.00 & 1.00 & 0.00 & 1.00 & 0.00 & 1.00 \\
\hline 14 & $\begin{array}{c}\text { D.I } \\
\text { YOGYAKARTA } \\
\end{array}$ & 0.88 & 0.93 & 0.68 & 1.00 & 0.87 & 0.92 & 0.88 & 0.94 \\
\hline 15 & JAWA TIMUR & 0.02 & 1.00 & 0.02 & 1.00 & 0.00 & 1.00 & 0.00 & 1.00 \\
\hline 16 & BANTEN & 0.00 & 1.00 & 0.01 & 1.00 & 0.08 & 1.00 & 0.13 & 1.00 \\
\hline 17 & BALI & 0.93 & 0.81 & 0.94 & 0.83 & 0.93 & 0.81 & 0.94 & 0.76 \\
\hline 18 & NTB & 0.96 & 0.94 & 0.97 & 0.93 & 0.97 & 0.92 & 0.97 & 0.90 \\
\hline 19 & NTT & 0.99 & 1.00 & 0.99 & 1.00 & 0.99 & 1.00 & 0.99 & 1.00 \\
\hline 20 & $\begin{array}{c}\text { KALIMANTAN } \\
\text { BARAT } \\
\end{array}$ & 0.67 & 0.87 & 0.72 & 0.86 & 0.82 & 0.86 & 0.87 & 0.86 \\
\hline 21 & $\begin{array}{c}\text { KALIMANTAN } \\
\text { TENGAH }\end{array}$ & 0.76 & 0.89 & 0.78 & 0.89 & 0.82 & 0.90 & 0.80 & 0.88 \\
\hline
\end{tabular}

\begin{tabular}{|c|c|c|c|c|c|c|c|c|c|}
\hline 22 & $\begin{array}{c}\text { KALIMANTAN } \\
\text { SELATAN }\end{array}$ & 0.85 & 0.86 & 0.87 & 0.97 & 0.89 & 0.86 & 0.88 & 0.82 \\
\hline 23 & $\begin{array}{c}\text { KALIMANTAN } \\
\text { TIMUR } \\
\end{array}$ & 0.00 & 0.97 & 0.05 & 0.98 & 0.10 & 0.979 & 0.08 & 0.96 \\
\hline 24 & $\begin{array}{l}\text { SULAWESI } \\
\text { UTARA }\end{array}$ & 0.91 & 1.00 & 0.92 & 1.00 & 0.94 & 1.00 & 0.95 & 1.00 \\
\hline 25 & $\begin{array}{l}\text { SULAWESI } \\
\text { TENGAH }\end{array}$ & 0.95 & 0.94 & 0.94 & 0.92 & 0.93 & 0.90 & 0.75 & 0.90 \\
\hline 26 & $\begin{array}{l}\text { SULAWESI } \\
\text { SELATAN }\end{array}$ & 0.67 & 0.98 & 0.64 & 0.98 & 0.36 & 0.97 & 0.08 & 0.95 \\
\hline 27 & $\begin{array}{l}\text { SULAWESI } \\
\text { TENGGARA }\end{array}$ & 0.93 & 1.00 & 0.94 & 0.95 & 0.94 & 0.93 & 0.87 & 0.91 \\
\hline 28 & GORONTALO & 0.99 & 1.00 & 0.99 & 1.00 & 0.98 & 1.00 & 0.98 & 1.00 \\
\hline 29 & $\begin{array}{c}\text { SULAWESI } \\
\text { BARAT }\end{array}$ & 0.00 & 1.00 & 0.00 & 1.00 & 0.74 & 1.00 & 0.00 & 1.00 \\
\hline 30 & MALUKU & 0.97 & 1.00 & 0.96 & 1.00 & 0.96 & 1.00 & 0.97 & 1.00 \\
\hline 31 & $\begin{array}{c}\text { MALUKU } \\
\text { UTARA }\end{array}$ & 0.97 & 1.00 & 0.97 & 1.00 & 0.96 & 1.00 & 0.93 & 1.00 \\
\hline 32 & PAPUA BARAT & 0.00 & 1.00 & 0.00 & 1.00 & 0.00 & 1.00 & 0.00 & 1.00 \\
\hline 33 & PAPUA & 0.86 & 0.82 & 0.00 & 0.81 & 0.00 & 0.79 & 0.00 & 0.82 \\
\hline
\end{tabular}

Table 3 is a table showing a statistical summary Table 2 to pursed into four analytical results, namely; First, the average of the measurement of the efficiency of the manufacturing industry in 33 provinces in Indonesia have increased and then decreased until the end of 2015. On the measurement of the efficiency of using the UEN, in 2012 the average score of efficiency of 33 provinces in Indonesia stood at 0.5580 , had decreased in 2013 to 0.5176 , the efficiency score had increased again in 2014 and then slumped back to the 0.5065 figure in 2015. in contrast to previous efficiency measures, UENM showed a downward trend although it had little to increase in 2013. in 2012 the figure 0.9618 , the score of efficiency was increased by 0.9670 in 2013 , but the score is experiencing a declining trend until reaching 0.9444 at the end of the observation.

\section{TABLEIII. RESULTS OF STATISTICAL DISPERSION UEN EFFICIENCYAND UENM 33 PROVINCES INDONESIA}

\begin{tabular}{|c|c|c|c|c|c|}
\hline Industry & \multicolumn{5}{|c|}{ Manufacture } \\
\hline Year & $\mathbf{2 0 1 2}$ & $\mathbf{2 0 1 3}$ & $\mathbf{2 0 1 4}$ & $\mathbf{2 0 1 5}$ & overall \\
\hline statistic & \multicolumn{5}{|c|}{ Unified efficiency under natural disposability (UEN) } \\
\hline Avg & 0.5580 & 0.5176 & 0.5506 & 0.5065 & 0.5332 \\
\hline Max & 0.9933 & 0.9934 & 0.9946 & 0.9977 & 0.9948 \\
\hline Min & 0.0000 & 0.0000 & 0.0000 & 0.0000 & 0.0000 \\
\hline SD & 0.3975 & 0.4166 & 0.4067 & 0.4087 & 0.4074 \\
\hline statistic & Unified efficiency under natural \&manajerial disposability \\
\hline Avg & 0.9618 & 0.9670 & 0.9570 & 0.9444 & 0.9576 \\
\hline Max & 1.0000 & 1.0000 & 1.0000 & 1.0000 & 1.0000 \\
\hline Min & 0.8116 & 0.8146 & 0.7961 & 0.7677 & 0.7975 \\
\hline SD & 0.0552 & 0.0531 & 0.0586 & 0.0703 & 0.0593 \\
\hline
\end{tabular}


Second, high efficiency scores on measurements UEN of UENM, because UENM measurement due not only to measure the operational efficiency alone but also categorize the environmental performance as one of the factors efficiency measurement. Third, the difference between natural and managerial disposability can be seen through the effect of capital indices described in Fig. 1, which is the average UENM the manufacturing industry sector is higher than the average UEN. For example, the average overall (overall) UEN UENM by 0.5332 and 0.9576. The figure indicates that the manufacturing sector's 33 provinces in Indonesia under measurement UENM have increased the amount of capital assets whereas in others under measurement UEN all input must be scaled back investment is no exception.

Lastly, the difference of the UEN and UENM most striking is the capital treatment of the index, the UENM manufacturing sector in Indonesia to invest in capital assets for the development of technological innovation aimed at improving the operational and environmental performance. Therefore, through this research can be confirmed that the Porter hypothesis applies to the manufacturing industry in Indonesia.

\section{Inefficiency Resource}

The popularity of DEA in measuring efficiency has been widely known to researchers as the analyzer can evaluate the performance of a DMU is based on an index range between 0 (full inefficiency) and 1 (full efficiency). Some DMU showed the best performance with the indexshows unity in the measurement of efficiency. However, there are several other DMU which shows the level of their inefficiencies so that the measurement of their efficiency is less than 1. By measuring the level of efficiency, DEA can provide policy advice to DMU inefficient to give a figure of how many factors that should they need to improve or how much slack should be reduced to achieve the status of full efficiency.

In this section, this study wanted to show any production factor that is the source of the inefficiency of each DMU to see the amount of slack of the DMU. In section 5.1 the author examines the overall performance of 33 DMU using two measurement efficiency. At each measurement efficiency will be appear slack for each factor of production from DMU less or inefficient, therefore to see any factor of production that can make inefficient DMU author identifying the level of each of each slack. Objectively speaking authors in this study perform ratio measurements for each slack is adjusted by the total amount of slack adjusted. For example, for each level of the inefficiencies associated with the input $\mathrm{i}(\mathrm{i}=1$, . . .,m) which calculated by $\mathrm{R}_{i}^{\mathrm{x}} \mathrm{d}_{i}^{x^{*}} /\left(\sum_{i=1}^{m} \mathrm{R}_{i}^{\mathrm{x}} \mathrm{d}_{i}^{x^{*}}+\right.$ $\left.\sum_{r=1}^{s} R_{r}^{g} d_{r}^{g^{*}}+\sum_{f=1}^{h} R_{f}^{b} d^{b^{*}}\right)$ for model (3), , $\mathrm{R}_{i}^{\mathrm{x}} \mathrm{d}_{i}^{x^{-} *} /\left(\sum^{m_{-}}\right.$ $\left.{ }_{i=1} \mathrm{R}_{i}^{\mathrm{x}} \mathrm{d}_{i}{ }^{x-*}+\sum_{q=1}^{m+} \mathrm{R}_{q} \mathrm{~d}_{q}{ }^{x+*}+\sum_{r=1}^{s} R_{r}^{g} d_{r}^{g^{*}}+\sum_{f=1}^{h} R_{f}^{b} d_{f}^{b^{*}}\right)$ for the calculation of the labor and energy consumption model (5) and $\mathrm{R}_{q}{ }^{\mathrm{x}} \mathrm{d}_{q}{ }^{x+*} /\left(\sum_{i=1}^{m} \mathrm{R}_{i}^{\mathrm{X}} \mathrm{d}_{i}^{x^{*}}+\sum_{r=1}^{s} R_{r}^{g} d_{r}^{g^{*}}+\right.$ $\sum_{f=1}^{h} R_{f}^{b} d_{f}^{b^{*}}$ ) for calculation of capital investment in the model (5). The denominator of the ratio above indicated level of inefficiency that can also be expressed through the right side of the same as in equation (4) and (6).

Fig. 2. shows the slack changes every year used to measure how much the UEN on the manufacturing sector in Indonesia. Fig. 2. also indicates that the two variables undesireable output $\left(\mathrm{NO}_{\mathrm{X}(2)}\right.$ and $\left.\mathrm{SO}_{\mathrm{X}(2)}\right)$ has the trend is up and down, on the other hand, the biggest source of inefficiency from high energy use in the manufacturing sector in Indonesia. However, the downward trend in output undesireable $\mathrm{NO}_{\mathrm{X}(2)}$ and $\mathrm{SO}_{\mathrm{X}(2)}$ stable at the end of the observation as well as the decline in investment and energy consumption is critical to achieving efficiency score higher on measures UEN Indonesian manufacturingindustry.

E UEN E UENM

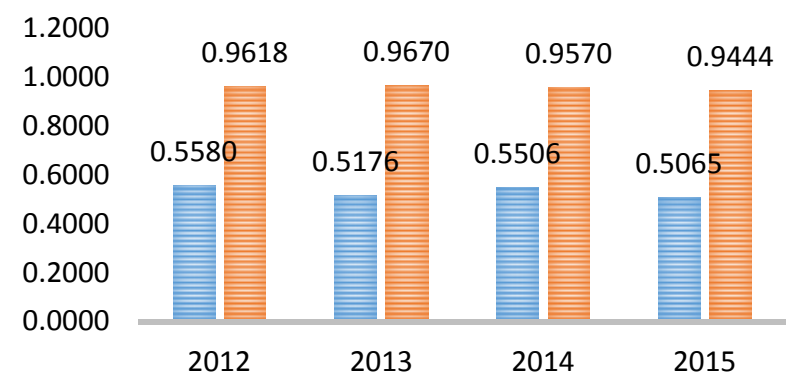

Fig.2. Measurementof Efficiencyand UEN UENin 33 Provincesin Indonesia.

Fig.4 indicates the slack changes every year from UENM measurement. Fig.3 and Fig.4 has some similarities than differences in the number of input and output variables that must be reduced, especially on variable energy consumption, investment, and GDP in the manufacturing industry.Energy consumption in this study to be one of the biggest factors causing inefficiencies in the manufacturing sector in 33 provinces in Indonesia. Incomparison, Fig. 3 and Fig.4 visually indicating that themanufacturing industry in Indonesia can achieve optimal efficiency score well on UEN and UENM withlower levels of undesireable output. The difference in the two figures can also be found on the level of investment and the GDP. Thus in Fig. 3 indicating the high absorption of investment funds for mecapai score on UENM optimal efficiency.

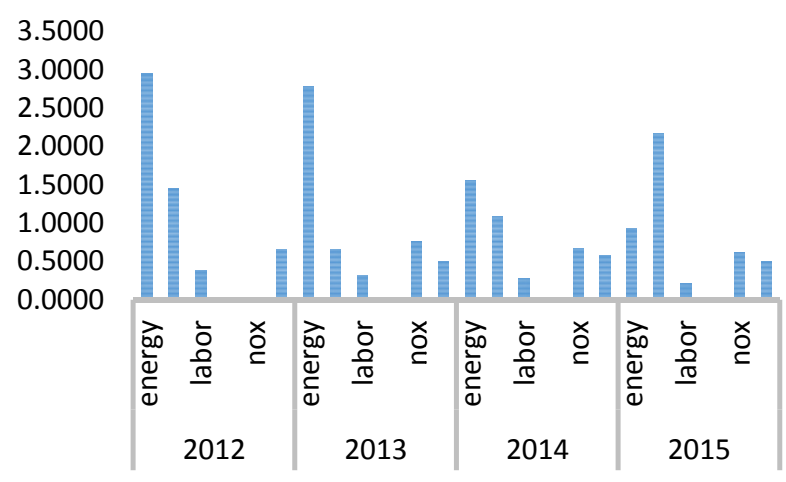

Fig.3. SlackManufacturingSectorin 33 Provincesin Indonesia UEN Measurement.

But unfortunately, the manufacturing industry in Indonesia, the high rate of the GDP is still one significant source of inefficiency in UENM measurement. This is due to a lack of alignment between the use of energy, reduction of output undesireable, as well as undesireable 
reduction in output. That phenomenon may occur due to the lack of law enforcement on policy implementation of environmental policies on the manufacturing industry in Indonesia.

So based on the difference in the measurement of the efficiency, the least amount of slack to be reduced to indicate that the manufacturing industry in Indonesia has effectively use investment as a factor in achieving optimum efficiency scores in measurements UENM. The investments were used to increase production facilities as well as to increase production in harmony with environmental improvements. Such improvements can be implied as technological innovation to environmental protection as a top priority of the UEM is to increase environmental performance, which was followed by an increase in operational performance.

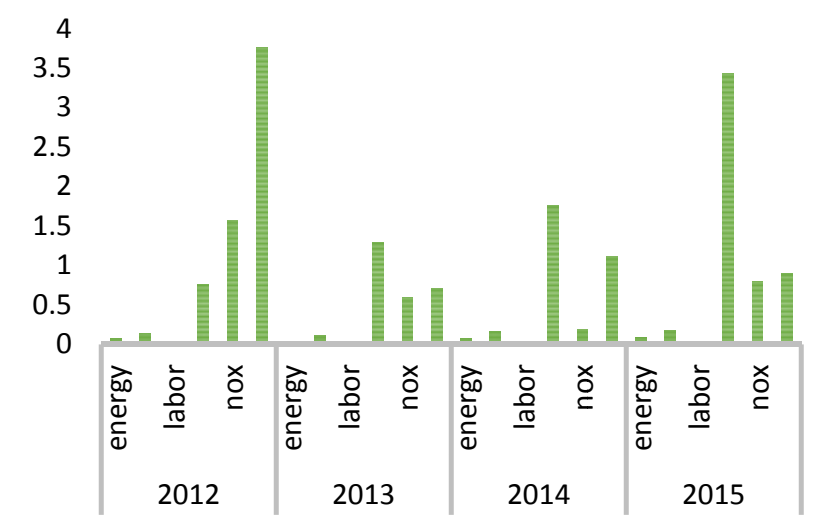

Fig. 4. SlackManufacturingSector 33

ProvincesinIndonesia onTheMeasurement UENM.

\section{The Differences in efficiencies in each Provinces}

Back in Table 2, Fig.5 and Fig.6 depicts two measurements of the efficiency of the manufacturing industry in 33 provinces of Indonesia. On the measurement of these two measures of efficiency, we can see a different pattern on each province observations. For example, the measurement UEN seen in Fig. 4. provinces provinces with industrial growth massive such as Riau, West Java, Central Java and East Java had scores lowest efficiency in the manufacturing sector, unlike the scores of efficiency in measurement UENM, these four provinces can be reached score maximum efficiency. This indicates that these four provinces have the potential to maximize the efficiency of both the environment and operational efficiency by changing the structure of industrialization and start using environmentally friendly technological innovation, particularly to improve the performance quality of their environment.
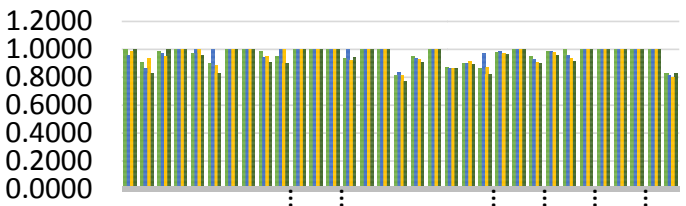

0.0000

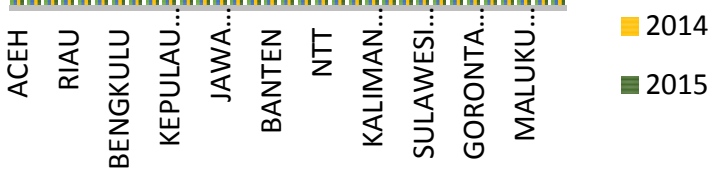

Fig.5.

EfficiencyScoreinManufacturingIndustryeachProvinces inIndonesia in UEN Measurement.

Similarly, Lampung, Riau, Banten and East Kalimantan. Four provinces also have the highest efficiency score rarely even tend inefficient at UEN measurements, but can drastically improve their efficiency scores in measurements UENM. It also indicates that the majority of the manufacturing industry in the province in the Indonesian provinces need to invest in innovation uptake of environmentally friendly technologies in the production process.

\section{$-2012 \square 2013 \square 2014 \square 2015$}

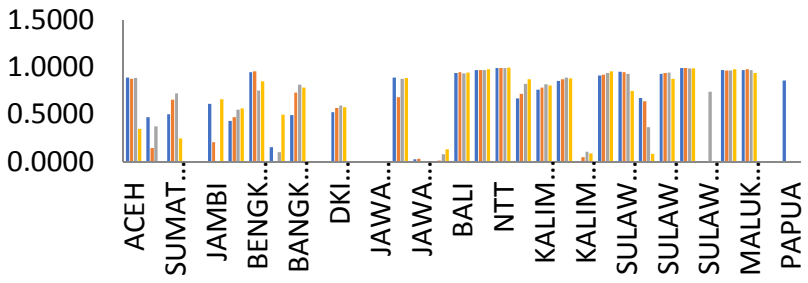

Fig.6. Efficiency Score in Manufacturing Industry each Provinces in Indonesia in UENM Measurement.

\section{CONCLUSION}

In this study, the authors apply two performance measurement model to a data set consisting of the data of manufacturing industry sector in 33 Indonesian provinces, to determine whether the Porter hypothesis may apply to the manufacturing industry in Indonesia or not. Empirical results indicate that the Porter hypothesis can be applied to manufacturing industry in Indonesia.

- First, the measurement UENM observation manufacturing industry sector in 33 provinces during out from 2012 to 2015, the majority of efficiency has increased.

- Second, two undesireable output can be suppressed in the second fine measurement UEN and UENM, but unfortunately the level of energy consumption in the production process in Indonesia on measuring UEN still the biggest factor inefficiency.

- Third, the amount of investment can also cause inefficiency in the measurement UEN, but in contrast to UENM that absorbs investment funds very well by investing in asset production assets and environmental protection.

This study has weaknesses that can be explored further in future research, exploration primarily on the 
model UENM highly dependent on macroeconomic conditions, the investment cycle, as well as other regional factor factor.

\section{REFERENCES}

[1] L. Yangand K. L. Wang, "Regional Differences of environmental Efficiency of China's Energy Utilization and Environmental Regulation Cost Based on Provincial Panel Data and DEA Method," Mathematical and Computer Modelling, vol. 58, pp. $1074-1083,2013$.

[2] D. I.Stern, M. S.Common, and E. B. Barbier, "Economic growth and environmental degradation: The environmental Kuznets curve and sustainable development," World Dev, vol. 24,pp. 1151-1160, 1996.

[3] A. B. Jaffe, Peterson, S. R., Portney, P. R. and Stavins, R. N., "Environmental Regulation and the Competitiveness of U.S. Manufacturing: What Does the Evidence Tell Us?," Journal of Economic Literature, vol. 23, pp. 132-163, March 1995.

[4] P. Yusgiatoro, EkonomiEnergiTeoridanPraktek, Jakarta:Pustaka LP3ES, 2000.

[5] A.Charnes, W.Cooper, andE. Rhodes, "Measuring The Efficiency of Decision-Making Units,"European Journal of Operational Research, vol 2, pp. 429 -444, 1978.

[6] D.Hawdon, "Efficiency, Performance, and Regulation of the International Gas Industry - a Bootsrap DEA Approache," Energy Policy, 11th ed.,vol. 31, pp. 1167-1178, 2003.

[7] R.D.Banker, A. Charnes, and W. W. Cooper,"Some Models for Estimating Technical and Scale Inefficiencies in Data Envelopment Analysis," ManagementScience,9th ed., vol. 30, pp. 1078-1092, September1984.

[8] C. Peroni, "Environmental Efficiency Indices: Towards a New Approach to Green - Growth Accounting,"Economie et Statistique, Working Paper du STATEC N61, Ministre de l'economie e du commerce exterieur du Grand-Duch de Luxembourg, 2012.

[9] T. Sueyoshi, M. Goto, and M. A. Snell, "DEA environmental assessment: Measurement of damages to scale with unified efficiency under managerial disposability or environmental efficiency," Applied Mathematical Modelling, vol. 37, pp. 7300-7314, July 2013.

[10] A. Otsuka, M. Goto, and T. Sueyoshi, "Energy efficiency and agglomeration economies: the case of Japanese manufacturing industries," Regional Science Policy and Practice, 2nd ed., vol. 6, pp. 195-212, 2014. 